\title{
Fr Francis Mihalic and Wantok niuspepa in Papua New Guinea
}

ABSTIRACI

Papua New Guinea's Tok Pisin language newspaper Wantok, founded in 1969 , is one of the publishing icons of the South Pacific. Drawing on interviews with Fr Francis Mihalic and Bishop Leo Arkfeld made in the early 1990s, a manuscript history of the early days of the Wantok, written by Mihalic, and material drawn from the archives in the Society of the Divine Word's mother house in Mt Hagen, this article seeks to present a picture of a man who was at once a priest, a publisher, a propagandist, a linguist, a lecturer and often a cause of bewilderment to the very bishops whose work he was supposed to be doing. While acknowledging Mihalic's role as the creator of Wantok, it places the emergence of the newspaper within an historical, educational, religious and social framework that shows it emerging and growing in response to several broad trends.

Keywords: development communication, Divine Word, ecumenical, language, Tok Pisin, vernacular publishing, Wantok

PHILIP CASS

Unitec, Auckland

$\mathrm{F}$ ATHER FRANK MIHALIC is the name most commonly associated with Papua New Guinea's Tok Pisin newspaper, Wantok. He could certainly claim to be the papa bilong Wantok, but the idea for the paper was not his. He was not even the first choice for the job and he may well have been much happier writing radio scripts than editing a newspaper. Mihalic's order, the Societas Verbo Divini, more commonly known as the Society of the Divine Word or SVDs, had a long history of printing and publication. They had already published a Tok Pisin monthly, Frend Bilong Mi, in manuscript from 1935 and then in print from 1940.(Baker, 1944) Wantok grew out of that tradition and from the Second Vatican Council, which began in 1962. Among the most important documents of the council was Communio 
et Progressio, which laid out a set of beliefs about the importance of communication in the life of the Catholic church. (www.vatican.va/roman_curia/pontifical_councils/pccs/documents/rc_pc_pccs_doc_23051971_communio_en.html)

Communio et Progressio reflected the church's commitment to working with the poorest people, something that was especially important in places like the Territory of Papua and New Guinea where there was widespread illiteracy, poor nutrition, a high infant mortality rate and constant fear of tribal warfare and sorcery in remote or recently contacted areas. Fr Jim Franks, who became head of Wantok's parent company, Word Publishing, said that Wantok was 'a child of Vatican II' whose job was to show that there was 'a Christian as well as an economic and political viewpoint'. (Franks, video, 1990)

From the beginning, Wantok set out to serve the needs of ordinary people and to provide them with a voice. Along with the news it has also brought to its readers political education, advice on social, agricultural and public health issues, education and human rights. Robie (2004) has described Wantok as 'a benchmark of national development and the contribution that good journalism can make to education at grassroots level.'

Some time in the early 1990s, Mihalic put together an account of the struggle to launch Wantok. 'Pipe dreams vs Facts of Life: Wantok's Wewak Years (1969-1976)' can be viewed as an attempt to set the record straight from his point of view at a particular time in his life. He could reasonably have thought he had ended his working life and had time to look back and assess what he had done. Mihalic had been as tireless a propagandist for Wantok as he was for Tok Pisin and this meant that his name became indelibly linked with the paper he started. However, it seems fair to place Wantok within a tradition of SVD printing and to acknowledge that he had initially been brought in to make somebody else's idea a reality. Indeed, later in his life Mihalic reflected that most of his career had been devoted to helping 'to start something or keep [it] going'(www.svd-ca.com/mihalic.htm).

Mihalic is quite rightly honoured for his work as the founder of Wantok, but there are times, in his writings and other communications, when, as with anybody driven by one goal, he can sometimes seem to have been indifferent to other people's opinions and single minded in pursuit of his own objectives. 'Pipe Dreams vs Facts of Life' presents a picture of a man who sometimes took a very caustic view of his religious confreres and the business of 
running a newspaper. However, it is doubtful whether a person not as apparently driven or single minded could have brought Wantok into being and nursed it through its troubled early years.

When I interviewed Mihalic on Kairiru Island in April 1992 it was obvious that his confreres revered him, just as his journalism students at the Divine Word University did. His fellow religious on Kairiru were solicitous of his health and concerned that I did not over-tire him. Mihalic gave me a copy of his manuscript with instructions that I was not to quote from it without his permission. His death has, I believe, freed me from that obligation.

Francis Mihalic was born to migrant parents in the United States on November 24, 1916 (Post-Courier, 2001, December 11). His father was Croatian, his mother Slovakian and he was one of ten children in a poor family. His was a conventionally Catholic family in an age when vocations were encouraged. Mihalic had completed high school and two years of tertiary education before he decided to become a priest and join the SVDs as a postulant. In an age when boys could enter a junior seminary in their teens, Mihalic's was almost a late vocation. Mihalic's mother was delighted when he was accepted into the seminary, but his father was reported to have felt 'short-changed by the Lord' (www.svd-ca.com/mihalic.htm)1.

Mihalic was ordained in 1944. Having studied philosophy, theology, Greek and Latin, he also obtained a basic medical education at the Chicago College of Medical Technology. He was asked to stay in at the SVD seminary in Techny and teach physiology and geology until 1947 when he was ordered to what was then the Territory of Papua and New Guinea.

Conditions throughout the Territory were chaotic, with almost nothing left standing after three and-a-half years of war. At the SVD's headquarters in Alexishafen, which had once boasted its own brass band, a horse-drawn railway and extensive coconut plantations, there was only rubble. The missionaries lived in what were little more than humpies made from scrap iron.

Our homes are like our Lord's tomb: close to the ground. They are ramshackle lean-to's of termited timber holding aloft a tin roof- for the time being. We have gunny sack walls and rainwater for drinking and washing. The work most of us priests did...[ ]...was anything but clerical: overhauling Jeeps, servicing diesel boat motors, hauling supplies by air and land and sea, setting up leftover army machinery and building. (Matbob, 2010a) 
Mihalic was sent to work in the Eastern Sepik District where he presided over the parish at Marienburg. Among his parishioners was a young Michael Somare, who would become PNG's first Prime Minister. While in the Sepik, Mihalic began to compile material on Tok Pisin. The SVDs had been the first missionary group to formally adopt Tok Pisin as a lotu language; that is, a language of evangelisation in the 1920s. They did this reluctantly, but it was a practical solution to the Babel of languages around them. The other missions in New Guinea, whether Protestant or Catholic, used Tok Pisin for day to day communication, but insisted on using local languages-Tok Ples-as lotu languages, even if it meant, as the Lutherans did, imposing a language from one place on another (Cass, P., 1997).

A few months after his arrival in Marienburg, Leo Arkfeld, then Vicar Apostolic of Central New Guinea and later famous as the 'flying bishop' of Wewak, ordered Mihalic to rebuild the catechists' school on Kairiru Island. (www.catholic-hierarchy.org/country/bpg.html) Then, disaster struck. With his somewhat basic medical education, Mihalic had been able to obtain a license as a medical assistant, but while fighting the diseases rife in the area he contracted tuberculosis and in 1954, just six years after arriving in New Guinea, he was repatriated to the United States

While he was in a Californian sanatorium, he put together the material he had gathered in the Sepik into what would become the first proper Tok Pisin dictionary. Once he was out of hospital he enrolled in the Summer Institute of Linguistics language course and then started work on an MA thesis, but he was suddenly recalled to New Guinea and sent back to Kairiru. Mihalic fell ill again, but this time he was sent to Par in what is now Enga Province. The mountain air must have agreed with Mihalic because almost as soon as he arrived he was told that he was needed in Rome to help start the tertiate renewal programme.

It was while he was in Rome that the idea of a Tok Pisin newspaper, perhaps to replace Frend Bilong Mi or to meet the needs of a new audience, appears to have arisen. From surviving documents the idea probably came from Adolph Noser, Vicar Apostolic of Alexishafen from 1953 and Archbishop of Madang from 1966 (www.catholic-hierarchy.org/country/bpg.html).

Noser must have discussed the idea with his superiors, because a letter from the SVD Generalate to Noser dated 1964 survives, in which the project is discussed (SVD Generalate, letter, 1964). The names of a number of 
suitable priests to take charge of the project are included. Fr Bernie Fischer is mentioned, as is Fr Ralph Wiltgen, who had gone to Rome. So is Fr Mihalic, but the letter makes it clear that he wanted to stay in Rome and did not want to go back to PNG.

Plans for a newspaper appear to have simmered for several years until, in 1967, the Bishops' Conference of PNG asked him to come out from Rome and lay the foundations for a publication (Matbob, 2010a). Mihalic recalled: 'My job in Rome was by now running itself; I looked at this venturing into the unknown as a welcome challenge. I like challenges.' (Mihalic, personal communication, 1993)

Mihalic arrived in PNG in June 1967 to discover that nothing necessary for the production of a newspaper existed. He was to suggest what was necessary and let the bishops decide what had to be done. There were only two printing presses that might serve his purpose, one at Vunapope, headquarters of the Missionaires du Sacre Coeur (the MSCs, otherwise known as the Sacred Heart mission) in New Britain. The other was at the SVD mission at Wirui outside Wewak. Mihalic's head was full of ideas - a newspaper here, a printing press there, a bookshop over yonder and profits to be made from every enterprise. These were what Mihalic would later call the pipe dreams that became reality. As he was to discover, that reality could be harsh indeed.

What he was being asked to do was not, on the surface, too difficult: Start a newspaper for the indigenous people in Tok Pisin and do so in cooperation with another Catholic order which had a large printing press, a settled congregation, access to a distribution network and experience of producing publications in English, Tok Pisin and Kuanua.

It was not going to be that simple. There was no settled Tok Pisin orthography, except the one that Mihalic had developed. Various efforts had been to put Tok Pisin's house in order, but they had brought only partial order to the often wayward spellings and orthographic inexactitudes that plagued written versions of the language. There was a handbook of Tok Pisin for Administration officers, Mihalic's dictionary and soon there would even be a computerised concordance.(Laycock, 1970) There was a long history of different people attempting to establish one standard, people in Rabaul felt they knew how to spell Tok Pisin properly and so did people in Wewak and Madang and Lae and Port Moresby. Only in Samarai were they silent on the subject because in Milne Bay, as everybody there knew, they spurned Tok Pisin and spoke proper English.

214 PACIFIC JOURNALISM REVIEW 17 (1) 2011 
The churches all used different versions of Tok Pisin. After the Administration imposed its changes in education policy in the 1950s, the missions had to abandon their Tok Ples schools and teach children in English in order to receive their Administration subsidy. (Cass, L., 1975) This meant that the Tok Ples languages used by the Lutherans and Methodists in particular, Graged, Kate, Jabem and Kuanaua, had begun to imperceptibly lose their place as status languages as the language of the churches, the Tok Lotu, was slowly becoming Tok Pisin.

The greatest impetus in this direction was the decision by the Lutherans to translate the New Testament into Tok Pisin. Other denominations were drawn into one of the great ecumenical projects of the decade. The translation of the New Testament into the Gutnius Bilong Jisas Kraist was a pivotal moment in the history of Tok Pisin. It cemented the status of Tok Pisin as the Tok Lotu and lifted it above the ordinary categories of usage normally assigned to pidgins (Cass, P., 2000).

Mihalic arrived at a time when the first generation of school leavers to go through the Administration's all-English system were beginning to leave school. Not all of them had made it to Form Four (grade 10). Many were frustrated because although they had never mastered English they knew Tok Pisin. They wanted to know what was going on in the world, but had nothing available to meet their needs. Or had they?

Nelson's list of newspapers and magazines circulating in the Territory in 1967, the year Mihalic returned, includes a surprisingly large number of Tok Pisin publications, 11 of them produced by missions and 13 by the Australian administration (Nelson, 1967) (See Table 1). The fact that the Lutheran publications Kris Madang Totor and Aakesing were printed in both Tok Ples and Tok Pisin by the mid 1960s reflects the loss of an audience able to read in Tok Ples due to the Administration's education policies.

Among the papers circulating at this stage was NuGini Toktok, which had been produced on the north coast since the early 1960s. It was edited by Muttu Jawing Gare, who had joined the New Guinea Times Courier under the editorship of John Blair in 1959 and been encouraged to gather news for a Tok Pisin publication by Blair's successor, John Huxley (Marsh, ANGH Newsletter, 2004, December). NuGini Tok Tok first appeared on 4 October 1962. This was probably PNG's first attempt at a commercial Tok Pisin newspaper and pre-dated Wantok by eight years (Post-Courier, 2007, June 4). 
Table 1: Tok Pisin publications in 1967

\begin{tabular}{|c|c|c|c|}
\hline Name & Publisher & Location & Language \\
\hline Aakesing & Lutheran Mission & Madang & Kate/Tok Pisin \\
\hline Catholic Action & Catholic Mission & Monoita & English/Tok Pisin \\
\hline Council Gazette & Yabim-Kotte Council & Yabim-Kotte & Tok Pisin \\
\hline Council News & Local Govt Council & New Ireland & Tok Pisin \\
\hline $\begin{array}{l}\text { Eastern Highlands } \\
\text { Councillor }\end{array}$ & \begin{tabular}{|l} 
Eastern Highlands \\
Local Govt Council
\end{tabular} & $\begin{array}{l}\text { Eastern High- } \\
\text { lands }\end{array}$ & Tok Pisin \\
\hline Hahela Parish Bulletin & Catholic Mission & Bougainville & English/Tok Pisin/Tasi \\
\hline Harim & $\begin{array}{l}\text { Missionary Associa- } \\
\text { tion of PNG }\end{array}$ & Port Moresby & Tok Pisin \\
\hline Kamonrai & $\begin{array}{l}\text { Baluan Local Govt } \\
\text { Council }\end{array}$ & Manus & Tok Pisin \\
\hline Katolik & Catholic Mission & Vunapope & Tok Pisin \\
\hline Kris Madan Totor & Lutheran Mission & Madang & Graged/Tok Pisin \\
\hline $\begin{array}{l}\text { Leiwompa Council } \\
\text { News }\end{array}$ & Dept of Native Affairs & Lae & Tok Pisin \\
\hline Lutheran Mission News & Lutheran Mission & Madang & Yabim/Tok Pisin \\
\hline $\begin{array}{l}\text { Madang District Council } \\
\text { News }\end{array}$ & $\begin{array}{l}\text { Ambenob, Waskia } \\
\text { and Takia Local Govt } \\
\text { Councils }\end{array}$ & $\begin{array}{l}\text { Ambenob, } \\
\text { Waskia and } \\
\text { Takia }\end{array}$ & Tok Pisin \\
\hline New Guinea Lutheran & Lutheran Mission & Madang & $\begin{array}{l}\text { Different editions in Eng- } \\
\text { lish, Kate and Tok Pisin }\end{array}$ \\
\hline Nius Bilong Yumi & $\begin{array}{l}\text { Dept of Informa- } \\
\text { tion and Extension } \\
\text { Services } \\
\end{array}$ & Port Moresby & $\begin{array}{l}\text { Different editions in Tok } \\
\text { Pisin, English and Motu }\end{array}$ \\
\hline St Michael's Messenger & Catholic Mission & Kieta & Tok Pisin \\
\hline Sunday Text & Lutheran Mission & Madang & Tok Pisin/Graged \\
\hline Taladea Tavur & Dept of Education & Talasea & Tok Pisin \\
\hline Tamba & Dept of Native Affairs & Lae & Tok Pisin \\
\hline Tikana News & Dept of Native Affairs & Kavieng & Tok Pisin \\
\hline Tok Tok Bilong Kaunsil & Local Govt Council & Finchhafen & Tok Pisin \\
\hline $\begin{array}{l}\text { United Nations News- } \\
\text { letter }\end{array}$ & United Nations & Port Moresby & Police Motu/Tok Pisin \\
\hline Wastaua & \begin{tabular}{|l} 
International Bible \\
Students Association \\
(Jehova's Witnesses \\
\end{tabular} & Port Moresby & $\begin{array}{l}\text { Tok Pisin/ Printed in Eng- } \\
\text { lish as Watchtower and as } \\
\text { Gima Kohorona in Motu }\end{array}$ \\
\hline Wewak News & Dept of Native Affairs & Wewak & Tok Pisin \\
\hline
\end{tabular}

A sample of Tok Pisin publications in Papua New Guinea in 1967, the year Fr Mihalic returned to PNG to start work on what would become Wantok. Source: Nelson (1967). 
It was taken over by the Post-Courier when it merged with the New Guinea Times Courier and Gware became its editor (Post-Courier, 1969, June 30). He appears to have been the first New Guinean editor of a commercial newspaper. Described by Hastings and Hicks as a single sheet insert, it was distributed free to local government officers. It ran until 1970, and was then 'laid to rest without ceremony' (Hastings \& Hicks, 1972, p. 860).

In his recollections of the years leading up to the first publication of Wantok, Mihalic raised an important question: Why did the Catholic Church choose to produce a newspaper? Anybody looking at the Territory at the time, he wrote, would have surmised that the only possible road the church could follow was radio. There had been several cases in Africa involving failed printing exercises and it was deemed by the experts of the day that illiterate and widely scattered audiences could only be reached usefully and effectively with radio.

In view of this trend... anyone who was planning to start a newspaper in a virtually illiterate Third World country as primitive as New Guinea was deemed psychologically suspect. To complicate the plot still more [I] had no property, no staff, no journalistic experience and no promise of any funds from the bishops. (Mihalic, MS, undated)

Mihalic started his search in Vunapope, where, he said, Archbishop Hohne promised him a press, the use of ecclesiastical and lay staff and generally tried to persuade him that the Islands region was the best place to start a national Catholic newspaper because of its high rate of literacy (Mihalic, video, n.d). Archbishop Hohne presided over a large and very profitable diocese whose plantations and business interests allowed it to operate in rather grand style. As Mihalic told the story, the Archbishop offered him everything he could want, including land, staff and resources, but nothing materialised (ibid.). He would later accuse the Rabaul Archbishop of everything short of outright lying and accuse the MSCs of organising a campaign of slander against him. Years later Bishop Leo Arkfeld would claim, in a voice that bordered between horror and mockery, that the Archbishop drove around Rabaul in a large car flying the papal flag (Arkfeld, interview, 1992).

After his initial disappointment, Mihalic retired from the fray, but only for the moment. Into the breach stepped Bishop Arkfeld, who offered him a home and a printing press. With the aid of several SVD brothers and lay volunteers, the Wantok office was put together in less than four months. 
While looking for useful contacts in the run-up to the launch of Wantok, Ray Goodey, formerly in charge of the Vunapope press and now Mihalic's right hand man, was- according to one story-approached by the editor of NuGini Toktok in Lae who wanted to know if he was interested in buying a going concern rather than starting a new paper. In Port Moresby, John Ryan, who ran the short-lived New Guinea News Service was asked to supply copy to Wantok. Ryan said copy was supplied 'on a friendly basis simply because I believed strongly in the concept that the more newspapers PNG had the better-informed its people would be' (Ryan, personal communication, 2006; interview, 2006).

Back in Wewak, the training of local staff was underway. Goodey trained Brian Namiat of Torembi and Albert Singer of Kairiru as typists and taught Mihalic the basics of journalism. Meanwhile, Goodey's wife Francie trained a group of young local women in typing, filing and book keeping. They were Crescenti Clementi of Mushu Island, Maria Kovoingre of Boikin and Jacinta Jorgon of Marienburg. Jorgon began working for Wantok as a 15-year-old typesetter. She also helped with the circulation. Years later, Jorgon, who was still working for Wirui press, looked back on her days with Wantok with affection and declared that she loved every minute of it (Jorgon, interview, 1992).

Bishop Arkfeld presided over the launch of the first issue of Wantok on 5 August 1970 (Figure 1). A school choir sang at the opening and among its ranks was Anna Solomon, who would go on to become the paper's editor and publisher.

The late Sir John Guise [then Speaker of the House of Assembly] pressed the button to start the press rolling...[ ]...little did I know then that many, many, years later I would be the first Papua New Guinean editor of that newspaper. (Solomon, interview, 2007)

The presses produced 7000 copies of what was to be a fortnightly paper, but getting rid of them proved harder than expected. Attempts to sell it in the streets of Wewak failed because the schoolboys who were supposed to sell it baulked at the idea that people might think they were Jehovah's Witnesses selling the Watchtower. However, the paper was successfully sold at Catholic churches in the Momase region where the SVDs predominated and Divine Word University lecturer Patrick Matbob recalls his father buying it after mass. (Matbob, personal communication, 2007). Attempts to 

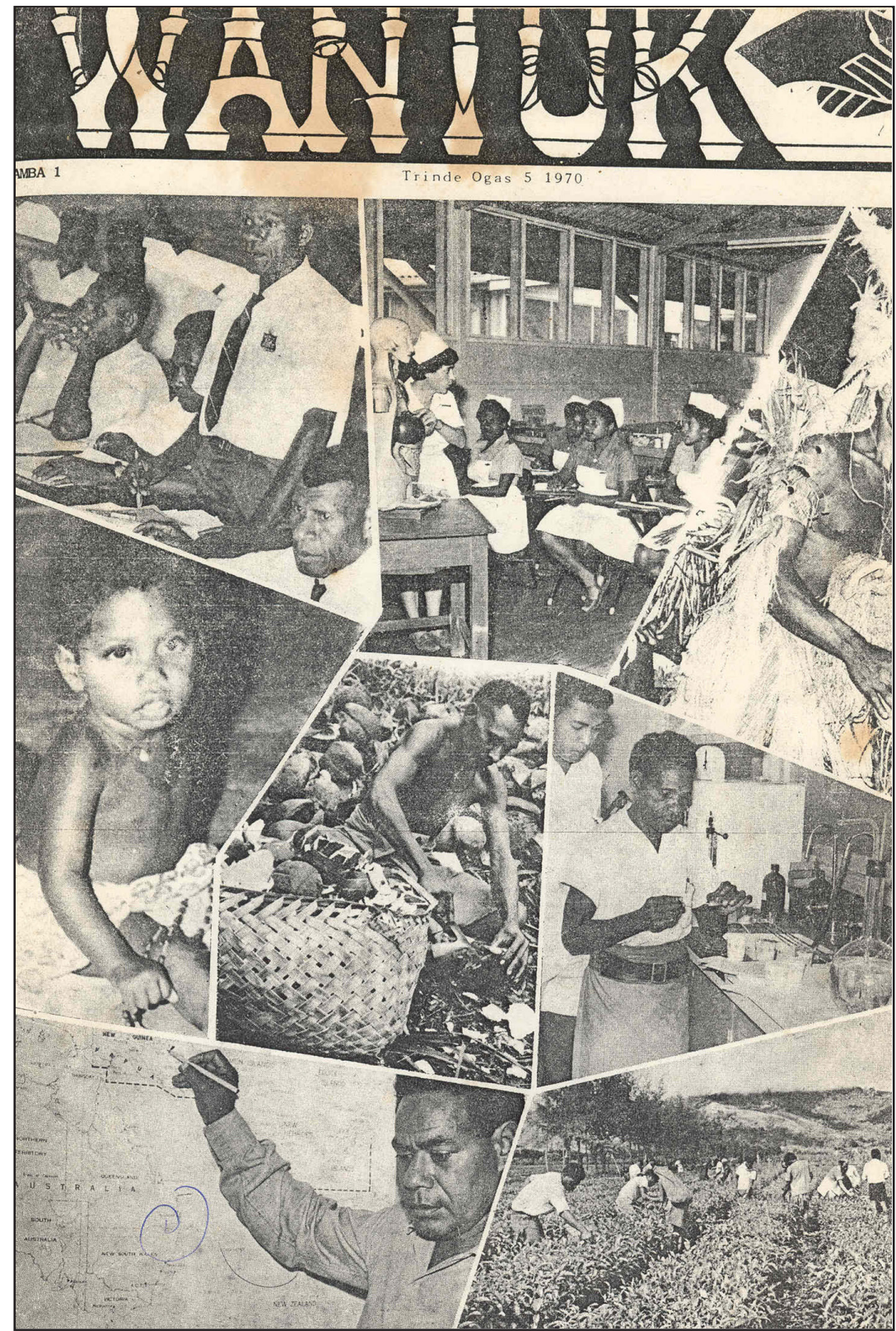

Figure 1: Wantok's first edition, 5 August 1970. The montage was made up of photos supplied by the Department of Information and Extension Services, which was always looking for outlets for its work. 
have the newspaper distributed in schools failed. Mihalic had expected that it would be a useful classroom tool, with its news stories and centrespread of government-supplied photos, but the Education Department was promoting the use of standard English in schools and Wantok was not taken up (Cass, P., 1999). Free bundles of the paper were sent to priests around the country with a suggestion that they be sold after mass on Sunday. Mihalic claimed that most priests refused to handle the newspaper because it was not completely Catholic.(Mihalic, MS, n.d) ${ }^{2}$

Wantok's first front page was a collage of official photographs provided by the Department of Information and Extension Services showing various aspects of life in PNG. The paper had a crude, hand-made look about it, but since its audience did not have any other source of printed news, this did not matter. It created its audience as it went along. In a country where, as Mihalic put it, there was no reading habit, the newspaper had to create one (Mihalic, video, n.d).

From the start, Wantok was aimed at the grasruts, the villagers cut off from large scale development, the school leavers looking for work and the urban dwellers, who might be public servants as much as drivers or haus bois. What they were most likely to have in common was an ability to read and write Tok Pisin.

The newspaper devoted a great deal of attention to explaining the changing political scene and explaining basic concepts. Wantok was broadly apolitical, but it certainly gave a lot of personal exposure to Michael Somare and the paper had very set opinions on certain topics. Cargo cults were clearly bad, as were secessionists of any kind. Margaret Mead was drafted in to declare that Papua Besena and the secessionists on Bougainville were longlong (mad) (Wantok, 23 July 1975). According to Matbob, the paper appealed to younger, literate people. One of the paper's most popular features was the large letters section which, from the beginning, attracted many students and teachers.

The front page editorial for the paper's 100th issue emphasised Mihalic's major concern that Tok Pisin speakers had no source of information in their own language and that, unless this was provided, their education would be largely wasted:

Wantokniuspepa i bin stat long yia 1970. Pater Mihalic, papa bilong em, $i$ wari olsem: Hia long Papua Nu Gini ol Kristen misin i save tromoim 
planti mani i go insait long of wok edukasen. Planti student $i$ pinisim praimeri skul tasol, na bikpela lain gen $i$ save lusim haiskul long Fom 2. Tru, ol i no inap ritim gut ol buk na niuspepa long tok Inglis.

Wantok $i$ wok long helpim ol dispela lain na ol narapela bikpela manmeri tu long ritim na raitim. Nogot edukasen bilong ol i pundaun nating. Wantok $i$ wok long givim ol kain kain nius $i$ laik kamap insait long PNG - bilong gavman, bisnis, na ol misin bai ol pipel $i$ save gut long kantri bilong ol.

(Wantok newspaper was started in 1970. Fr Mihalic, its founder, was worried that in Papua New Guinea Christian missions knew they had to spend a lot of money on education. Many students only finished primary school and many more left high school after form two [grade eight]. This meant they find it hard to read a newspaper or book in English. Wantok wants to help all these people and adults to read and write. Education shouldn't be wasted. Wantok's task is to bring you all kinds of news about government, business, missions and the people who know this country best.) (Wantok, 1974, September 18)

Mihalic's promotion of Wantok was fierce and sincere, but he seems not to have noticed or understood that other people might be equally as fierce about their own language or lingua franca. He poured scorn on priests in Papua who objected to being asked to circulate a Tok Pisin newspaper and declared that if only they had a Motu paper, it might become the equivalent of Wantok. Mihalic always felt that he had to defend himself and the paper, particularly against the charge that Wantok was insufficiently Catholic. As he explained time and again, it had never been intended to be what he called 'a mouthpiece for the bishops'. It had to be ecumenical to be truly Christian and because advertisers would not use a medium restricted to a narrow market (Figure 2). The bishops, he claimed, remained hostile or at best indifferent. Mihalic wrote to a friend that Bishop Noser had declared that the paper 'had done no harm' (The Word in PNG, 22 February 1975). As he ruefully noted on the paper's 20th anniversary:

I tru, ol bisop bilong PNG i bin givim namba wan aidia bilong kirapim dispela wok, tasol ol $i$ no bin sapotim em tumas.

(It's true that the bishops initiated this project, but since then they have given little support.) (The Word in PNG, 1990, August) 


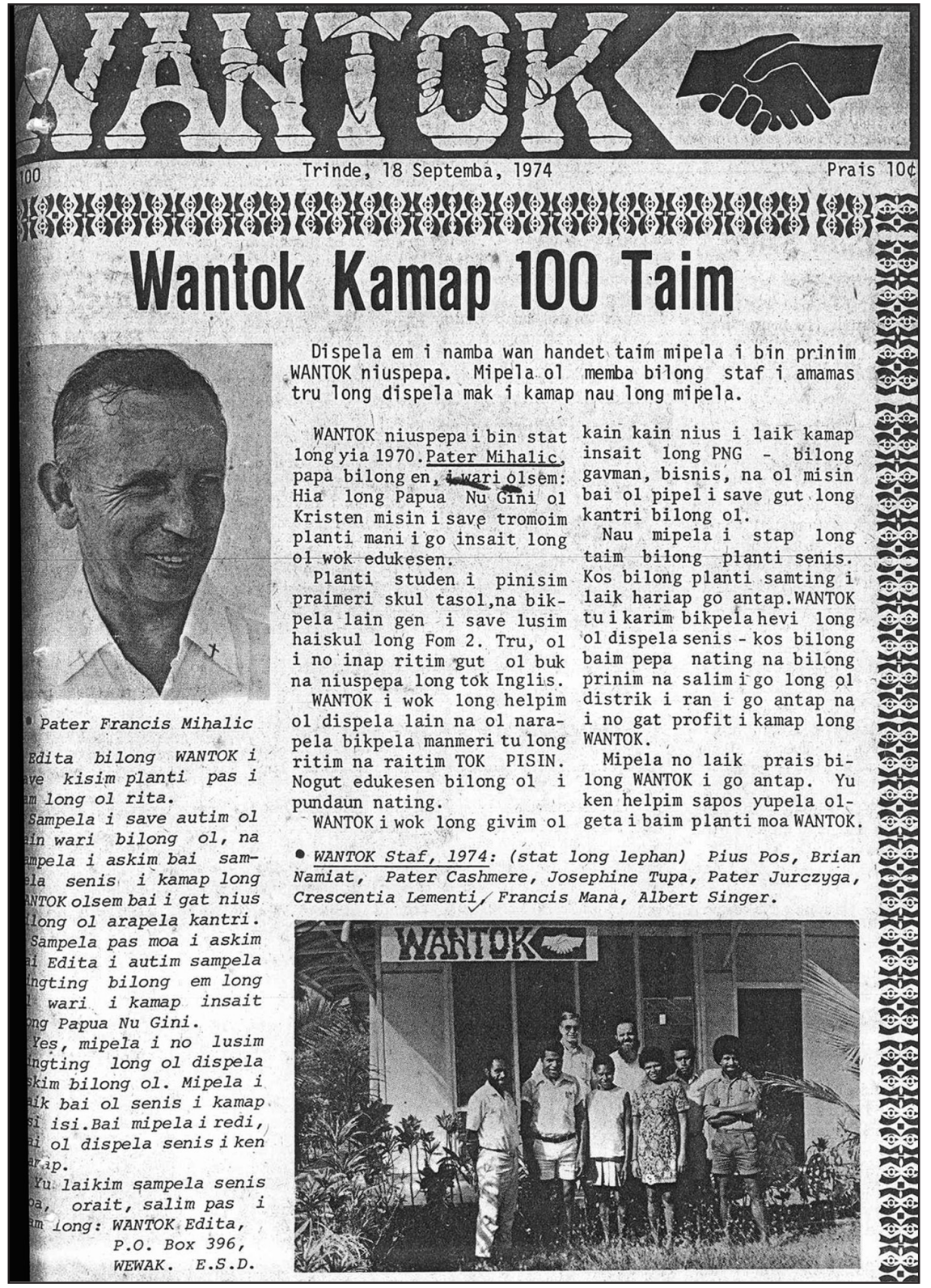

Figure 2: Father Frank Mihalic (top left) and Wantok staff at the time of the 100th issue in 1974: Pius Pos (from left), Brian Namiat, Pater Cashmere, Josephine Tupa, Pater Jurczyga, Crescentia Lementi, Francis Mana and Albert Singer. 
In 1976, Wantok moved to Port Moresby. Wewak was far away from the rest of the country and if the paper was to cover national events then it had to be near the seat of government. Mihalic gradually handed over the reigns of Wantok to Fr Jim Franks and for the next couple of years worked as a roving reporter for Wantok, The Times of PNG and New Nation. He also returned to his first love, radio features (Mihalic, personal communication, 1993).

In 1983, he was asked to join the newly established Divine Word Institute in Madang where he set up the journalism training school and for the next eight years used his expertise and experience to train the country's young aspiring journalists (Matbob, 2010a). After an all too brief retirement, he went back to DWI to inspire another generation of PNG journalists. He gave his last lesson on 7 August 1997. One of his students, Patrick Matbob, quoted Mihalic as saying:

All I had was 12 years of experience in newspaper editing, news gathering and reporting, proofreading, typesetting, page layout, advertising, distributing, photography and translation. (Matbob, 2010a)

Matbob recalled Mihalic as using his own experiences on Wantok to teach the fledgling journalists. He soon became more than their teacher.

He became 'the old man' and during weekends we would comb the school gardens to collect pawpaw for him. Apart from news writing, I loved his feature writing classes... He also taught us photography from taking pictures to developing them in his small dark room. Tok Pisin translation was another skill...which helped when we wrote for his baby, Wantok Niuspepa. I remember when I arrived in Port Moresby in 1985 to work...with Wantok, Anna Solomon, the editor, asked me to edit and lay out pages, take photographs, translate stories, and take down stories over the phone! No problem! Any of Mihalic's students knew exactly what to do. (Matbob, 2010a)

\section{Conclusion}

Mihalic left PNG for the last time in 1999. He died in the United States on 8 December 2001. During his lifetime, Mihalic's work in PNG was recognised several times. His dictionary remained in print until 1983, he translated the PNG constitution into Tok Pisin, wrote 30 books and was awarded an OBE and an honorary doctor of linguistics by the national University of Papua New Guinea (UPNG) (Matbob 2010a). 
Mihalic lived with an SVD community in California until his death. The community provide an online memorial to Mihalic which quotes at length from a piece he wrote in 1994. In it he reflected on his motivation and his life's work:

Playing second fiddle, doing ancillary or supportive work has been the story of my life. It has meant being a stopgap to fill some temporary need, or being a spare part that either helps to start something or keeps it going. The euphoria of being continually needed could easily have inflated my ego had I not luckily chanced upon a very sobering biblical text. One day I looked up the word 'need' in my concordance and was shocked to find out that only once in the entire New Testament had the Lord ever said that he had need of anything. It was the time he was going up to Jerusalem. He said he had need of a jackass! I took the hint. And ever since, Luke 19:34 has become my text. You will find it on my desk, scrawled across a snapshot of a genuine donkey patiently standing at the Damascus Gate. I have always admired the supportive staff of any organisation, the players who run interference for the ball-carrying football star, the mechanics who keep planes flying, the ground crew who nurse the space shuttle...I have no regrets. I feel quite fulfilled in having played a secondary role. Given the chance, I would gladly do it all over again —only better (www.svd-ca.com/mihalic.htm).

Frank Mihalic was not the first person to write a Tok Pisin dictionary-but he was the first person to write one that was successful and one that that is still regarded as the cornerstone of any work on Tok Pisin. He was not the first person to start a Tok Pisin newspaper, but he was the first person to start a Tok Pisin newspaper that became a national institution which serves the grasruts to this day.

\section{Notes}

1. The bulk of the material on Mihalic's early life is drawn from this obituary.

2. Mihalic says he sent it to 'missionary confreres'. This may indicate that it only went to SVD priests. If, however, he meant all Catholic priests, then it would have also gone to many districts where the Catholic church was represented by other missionary orders which perhaps did not take kindly to being asked to act as vendors for an SVD publication. Mihalic, F., 'Pipe Dreams vs Facts of Life...' 


\section{Interviews and personal communication}

Matbob, P. (2007, March 3). Personal communication with the author.

Mihalic, Fr. F. (1992, April 11). Interview with the author, Kairiru Island, PNG.

Mihalic, Fr F. (1993, August 20). Personal communication with the author.

Ryan, J. (2006, March 7). Personal communication with the author.

Ryan, J. (2006, June). Interview with the author, Rockhampton, Qld, Australia.

Solomon, A. (2007, January 25). Personal communication with the author.

\section{References}

All Bishops of Papua New Guinea. Retrieved on 7 January 2011, from www.catholichierarchy.org/country/bpg.html

Arkfeld, Bishop L. (1992, April 10). Interview, Divine Word Institute, Madang.

Baker, S. (1944). The literature of pidgin English. American Speech, 19(4).

Cass, L. (1975, September 29). Educational changes in PNG. Interview with NBC.

Cass, P. (1997). The apostolate of the press: Missionary language policy, translation and publication in German New Guinea. Unpublished MA thesis, Central Queensland University.

Cass, P. (1991). New Guinea's first newspapers: The missionary press in German New Guinea 1886-1914. Australian Journalism Review, 13(1-2), pp. 77-81.

Cass, P. (1999) Tok pisin and tok ples as languages of identification in Papua New Guinea. Media Development, 4; pp. 28-33.

Cass, P. (2000). Yu mas kamap wan nesen: The mainstream churches, tok pisin and national identity in Papua New Guinea. Paideuma: Mitteilungen zur Kulturkunde, 46; pp. 253-266.

Communio et Progressio. (1971, May 23). Retrieved on 7 January 2011, from www.vatican.va/roman_curia/pontifical_councils/pccs/documents/rc_pc_pccs_ doc 23051971_communio_en.html

Fischer, Fr B. (19922, December). Interview, Divine Word Institute, Madang.

Fr Francis Mihalic SVD: Great missionary, priest, newspaper editor, linguist, education, man of 'His Word'. Retrieved on 7 January 2011, from www.svd-ca.com/ mihalic.htm

Fr Jim Franks talks about Word Publishing. (1990). Video, produced by Christian Communications Centre, Goroka.

Fr Mihalic dies in California (2001, December 11) PNG Post-Courier.

Hastings, P. and Hicks, I. (1972). Newspapers and periodicals. In The Encyclopaedia of Papua New Guinea ( p. 860). Melbourne: Melbourne University Press.

Jorgon, J. (1992, April 9). Interview, Wirui mission, Wewak.

Life lessons from Father Mihalic (2001, December 12). PNG Post-Courier.

Marsh, D. (2004, December). Obituary of Keith Mattingley in Australian Newspaper History Group Newsletter.

Matbob, P. 92010a). Mihalic — wantok tru bilong PNG. MS.

Matbob, P. (2010b). Mihalic was my mentor. MS. 
Mihalic, Fr F. (1986). Tok pisin yesterday, today and tomorrow. Catalyst, 16(2); pp. 89-99.

Mihalic, Fr F. (n.d., but probably 1990-92). Pipe dreams vs Facts of Life: Wantok's Wewak Years (1969-1976). MS.

Mihalic, Fr F. (n.d., but probably 1990-92). The story of printing in the Wewak Diocese. MS.

Mihalic, Fr F. (c.1990). Unedited footage of interview shot at Divine Word Institute, Madang.

Nelson, H. (1967). The press in Papua and New Guinea. Paper presented at UPNG history research seminar, Waigani, October 25.

Obituary of John Huxley (2007, June 4). PNG Post-Courier.

Robie, D. (2004). Mekim nius: South Pacific media, politics and education. Suva:

USP Book Centre.

Stori Bilong Wantok. (n.d.). Video. Goroka: Christian Communications Centre.

SVD Superior Generalate (1964).letter to Bishop Adolph Noser, 8 October 1964.

The Word in PNG, (No.145, August 1990). No byline, but probably Mihalic.

Wantok, $40^{\text {th }}$ anniversary edition, August 2010.

Dr Philip Cass is post-graduate programme leader in the Department of Communication Studies at Unitec in Auckland. He has been a journalism and media educator in the Arabian Gulf, Australia, Britain, Fiji and Papua New Guinea. His doctoral thesis, People, politics and press in Papua New Guinea, 1950-1975, explored how the press in PNG reflected the rapid political and social changes from the end of the Second World War to the creation of an independent nation. This article is based on a paper presented to the Headliners journalism history conference, Mitchell Library, Sydney, November 2010.

pcass@unitec.ac.nz 